\title{
Materiality of Non-financial Sustainability Disclosures: Implications for the Business Enterprises in Bangladesh
}

\author{
Ashraf Al Mamun \\ Associate Professor, Bangladesh Institute of Bank Management (BIBM), Mirpur-2, Dhaka-1216, BANGLADESH \\ and PhD Candidate, Torrens University, Adelaide SA 5000, AUSTRALIA \\ E-mail for correspondence: ashrafalmamun@gmail.com
}

https://doi.org/10.18034/abr.v8i3.166

\begin{abstract}
In disclosing non-financial sustainability information, materiality of information may be a crucial factor to be considered, which is a new concept in sustainability reporting area. It outlines the significance of materiality assessments while realizing the content of sustainability reports with the identification of those economic, environmental and social issues that matter most to a company and its stakeholders. In this regard, GRI guidelines have been considered worldwide as a tool of disclosing non-financial material sustainability information by the business enterprises. The paper reviews relevant literature as methodology and discusses the conceptual framework of non-financial disclosure of material sustainability information and its implications for the business enterprises in Bangladesh. The paper finds that non-financial disclosure of material sustainability information is at a very nascent stage in Bangladesh and there is ample scope to disclosure of non-financial material sustainability information for the business enterprises in Bangladesh.
\end{abstract}

Key words: Materiality, non-financial disclosure, material sustainability information, sustainability reporting, GRI guidelines

\section{INTRODUCTION}

The concept and term of 'sustainability' have been evolving over the time (Rezaee, 2016). Classically, sustainability is used interchangeably based on 'sustainable development' which is defined broadly by World Commission on Environment and Development (WCED, 1987, p. 8) and focused on long time perspective in environmental, social, and economic context. Elkington (1997) linked the concept of sustainability in the case of business entities by terming it 'triple bottom line' of a company that covers economic, social and environmental aspects of a company. It is related to maintaining the physical and natural environment of a company while considering the economic and social considerations for doing business targeting the long-term value creation.

'Sustainability' is related with several contemporary business and reporting practices which include corporate social responsibility (CSR), corporate sustainability, corporate citizenship, integrated reporting, and sustainable entrepreneurship (Reddy and Gordon, 2010). More firms around the world use the word 'sustainability' instead of CSR (Khan et al. 2016). This paper does not draw any distinctions between sustainability and related terms.

The company stakeholders are increasingly emphasizing on the disclosure of its sustainability issues for the last few years (Tînjală, 2015) and sustainability reporting has become a progressively pertinent topic in the area of business and academia (Christofi et al., 2012). The generic term 'sustainability reporting' is used synonymously with 'Triple Bottom Line Reporting,' 'Corporate Responsibility Reporting', 'Corporate Citizenship Report,' and 'Community Report,' (Milne, and Gray, 2013). This paper uses the term 'sustainability report' for referring to mentioned variations of the term. The term 'reporting' and 'disclosure' are used in this paper interchangeably. For the last five decades (Perez and Sanchez, 2009) companies are disclosing their sustainability information which covers economic, social and environmental issues.

Compared to companies' financial reporting context, sustainability reporting is still in infancy (Tschopp, and Huefner, 2015). A sustainability report is a primary and leading concept to the companies' non-financial disclosure of sustainability issues. 
Companies' disclosures of non-financial sustainability reporting are encouraged by statutory as well as voluntary disclosure initiatives and guidelines (Milne, and Gray, 2013) which may be a stand-alone report or be integrated into the annual report as well as in their websites. Sustainability reporting is a tool for communicating sustainability information to a varied group of stakeholders (Gray et al., 2014, p. 3 and p.8) and as such the concept of disclosing material sustainability information to the stakeholders is vital.

The materiality of non-financial sustainability information disclosure is a new concept in the sustainability reporting area, which outlines the significance of materiality assessments while realizing the content of sustainability reports (Unerman and Zappepettini, 2014; Edgley et al., 2015). Materiality disclosure of non-financial sustainability information is related with recognizing those environmental, social and economic issues that matter most to a company as well as to its stakeholders.

Capital market participants are increasingly valuing companies with good environmental performance (Dhaliwal et al., 2012). There are some assumptions that the companies which disclose enough on the economic, social and environmental performance, should be valued highly in the capital markets, the results are not conclusive. Investors seem to respond positively to desirable sustainability information.

More than 8,000 global public companies are disclosing their non-financial environmental, social and governance (ESG) information through sustainability reports or in combination with other company reports (Rezaee, 2016 and 2017), which indicates its importance. Increased disclosure of sustainability information by the firms through non-financial reporting helps renew the trust of their stakeholders (including investors/shareholders, regulators, and consumers) in them as well as allowing the stakeholders to make informed decisions (Lydenberg, 2012). A large number of empirical studies (Moskowitz, 1972; Parket and Eilbirt, 1975; Vance, 1975; Sturdivant and Ginter, 1977; Abbott and Monsen, 1979; Cochran and Wood, 1984; Ullmann,1985; Griffin and Mahon, 1997; Waddock and Graves, 1997; McWilliam and Siegel, 2001; Van Dijken, 2007; Lin et al., 2009; Flammer, 2013; Lu, and Taylor, 2015; Choi and Moon, 2016; Kang et al., 2016; etc.) focused on CSR or ESG information and how such information impacts company performance. However, the studies did not investigate whether this information is material or not. A few studies (Khan et al., 2016; AmelZadeh, 2016; Lins et al., 2016; Jones et al., 2016; Eccles et al., 2012; Font et al., 2016; and Ong et al. 2016) that have been conducted so far in this area are based on the developed countries' context such as USA, UK, and Australia. As such it is relevant and significant to explore the concept of materiality of disclosure of non-financial sustainability information in the context of a developing country like Bangladesh.
Identifying the materiality of the non-financial sustainability information will add to the literature in a field that is increasingly gaining importance and guide the companies worldwide on what or what not to disclose. It will also generate useful information for corporate leaders and other policymakers in Bangladesh.

The broad objective of this paper is to discuss the conceptual framework of non-financial disclosure of material sustainability information and its implications for the business enterprises in Bangladesh.

After discussion of introduction and background in section 1, the article proceeds with the theoretical underpinning of non-financial disclosure of sustainability information in section 2 . Section 3 continues by defining materiality in the context of non-financial disclosure and use of global reporting initiative guidelines. It further discusses non-financial disclosure of material sustainability information and its implications for the business enterprises in Bangladesh in section 4. Section 5 concludes the article.

\section{Non-FINANCIAL Disclosure of SUSTAINABILITY INFORMATION: STAKEHOLDER THEORY AND LEGITIMACY THEORY}

There are two major theories in sustainability research, namely, stakeholder theory and legitimacy theory that offers a broad theoretical understanding about companies' approach to recognize the stakeholders' expectations and companies' legitimacy as seen by the social system in which they operate. Political economy perspective is the basis of both the theories (Deegan, 2002). Although there are differences in the conceptual framework of these two theories, the two overlaps (Deegan, 2002; Gray et al., 1995) and they focus on the interrelations between the organization and its surrounding environment in which it operates (Neu et al., 1998).

\section{Stakeholder theory}

Stakeholder theory provides a link between a company's stakeholders and its activities. Accordingly, in the form of a report, the stakeholders can be informed about companies' sustainability disclosures (Herremans, Nazari, and Mahmoudian, 2016). Stakeholders may affect a company's actions, objectives and policies, as well as they, may also be affected by the company. The organizations are likely to satisfy the stakeholders' demand as the stakeholder resources are critical to the achievement and viability of the organization (Ullmann, 1985). Also, the success of an organization is related with the fulfillment of the stakeholders' demand for organizations' different economic, environmental, and social information (Buchholz and Rosenthal, 2005; Laplume et al., 2008). Through sustainability report, an organization may try to meet the increasing stakeholders' 
demand for sustainability information (Deegan and Rankin 1997; O'Donovan, 2002; Ho and Taylor, 2007; Crawford and Williams, 2010).

Russo and Perrini (2010, p.209) states, "Non-financial reports are the means through which corporations become accountable for their strategy toward relevant stakeholders. Stakeholder theory taught good managerial and instrumental practices to firms". Sustainability reporting caters to the information requirements of different stakeholders by explaining them about companies' efforts to their information needs (Font et al., 2016). Thus, companies cannot deny the influence of their stakeholders while pursuing the creation of value through the companies' activities.

\section{Legitimacy theory}

Different sustainability disclosure related studies have been using the legitimacy theory. The widely used area of this theory is related with companies' environmental and social disclosures (Campbell et al., 2003, Tilling, 2004) and corporate disclosures are made to legitimize corporate actions (Guthrie, and Parker, 1989). Moreover, Cho et al. (2015) consider legitimacy as an imperative factor that affects environmental and social disclosures of a company.

Sustainability disclosures by the companies may increase their acceptability among different stakeholders within the social system. In this consideration, Talcot views legitimacy as the "appraisal of action in terms of shared or common values in the context of the involvement of the action in the social system" (Talcott, P., 1960, p. 175). According to the legitimacy theory companies must act upon a society's larger social system as well as a value system and legal framework to continue its operations (Lindblom, 1994, p. 2). Therefore, there is a need for congruency between existing social values and companies' business activities as well as information disclosure.

According to this theory, companies disclose sustainability information to increase the perception of the public about the companies' sustainability performance (Deegan, 2002). Besides, companies can gain competitive advantages over their contestants by disclosing adequate information to the relevant communities and societies (O'Donovan, 2002). On the other hand, companies may get the punishment for losing their license to operate in society if they breach a society's norms and expectations (Faisal et al., 2012). Thus, legitimacy theory posits that there is an implicit social contract between a business entity and society, conformity of which may be beneficial for a company or it may be detrimental for a company if it does not follow the society's values and norms.

The underlying process captured by these two theories suggests that the more the companies disclose their sustainability information on economic, environmental and social issues, the stronger may be their financial performance. Thus, together these two theories provide the conceptual underpinning for the present study.

\section{Defining Materiality in the Context of Non- FinANCIAL Disclosure AND USE OF Global REPORTING INITIATIVE (GRI) GUIDELINES}

The concept of materiality is primarily associated with financial reporting context and more specifically with the auditing and accounting processes of financial reporting. In terms of non-financial sustainability disclosure three definitions for defining materiality has been developed by the Sustainability Accounting Standard Board (SASB), Global Reporting Initiative (GRI) and the International Integrated Reporting Council (IIRC). The definitions are as follows:

SASB definition of materiality: SASB uses the U.S. Supreme Court's definition of materiality, which states, "Information is material if there is 'a substantial likelihood that the disclosure of the omitted fact would have been viewed by the reasonable investor as having significantly altered the 'total mix' of information made available" (SASB, 2016, p.7).

GRI G4 Guidelines Implementation Manual definition of materiality: It defines materiality as, "Material aspects are those that reflect the organization's significant economic, environmental and social impacts; or that substantively influence the assessments and decisions of stakeholders. To determine if an aspect is material, qualitative analysis, quantitative assessment and discussion are needed" (GRI, 2013b, p.244).

IIRC definition of materiality: It defines materiality as " $\mathrm{A}$ matter is material if it is of such relevance and importance that it could substantially influence the assessments of providers of financial capital with regard to the organization's ability to create value over the short, medium and long-term (IIRC, 2013, p. 2, available at. http:/ / www.theiirc.org/wp-

content/uploads/2013/03/IR-Background-PaperMateriality.pdf).

By analyzing the definitions provided by SASB, GRI and IIRC on disclosing material non-financial sustainability information, it is clear that a company should report the relevant information to allow stakeholders to evaluate the organization's capacity to create value in the short, medium to long term.

Table 1 compares the three frameworks of material nonfinancial information by the type of guidance, scale, scope, target disclosures, target reporters, target audience, type of organization providing the guidance. 
Table 1: Comparison of Guidance on Materiality from SASB, GRI and IIRC

\begin{tabular}{|c|c|c|c|}
\hline & SASB & GRI & IIRC \\
\hline $\begin{array}{l}\text { Type of } \\
\text { guidance }\end{array}$ & Standards & Standards & Framework \\
\hline Scale & U.S. & International & International \\
\hline Scope & $\begin{array}{l}\text { Industry } \\
\text { specific }\end{array}$ & General & General \\
\hline $\begin{array}{l}\text { Target } \\
\text { disclosure }\end{array}$ & $\begin{array}{l}\text { Mandatory } \\
\text { filing }\end{array}$ & $\begin{array}{l}\text { Voluntary } \\
\text { reporting }\end{array}$ & $\begin{array}{l}\text { Voluntary } \\
\text { reporting }\end{array}$ \\
\hline $\begin{array}{l}\text { Target } \\
\text { reporters }\end{array}$ & $\begin{array}{l}\text { Public } \\
\text { companies } \\
\text { traded on } \\
\text { U.S. } \\
\text { exchanges }\end{array}$ & $\begin{array}{l}\text { Public and } \\
\text { private } \\
\text { companies }\end{array}$ & $\begin{array}{l}\text { Public } \\
\text { companies } \\
\text { traded on } \\
\text { international } \\
\text { exchanges }\end{array}$ \\
\hline $\begin{array}{l}\text { Target } \\
\text { audience }\end{array}$ & Investors & $\begin{array}{l}\text { All } \\
\text { stakeholders }\end{array}$ & Investors \\
\hline $\begin{array}{l}\text { Type of } \\
\text { organization } \\
\text { providing } \\
\text { the guidance }\end{array}$ & $\begin{array}{l}\text { Independent } \\
501(\mathrm{c}) 3 \text { non- } \\
\text { profit }\end{array}$ & NGO & $\mathrm{NGO}$ \\
\hline
\end{tabular}

This study considers the GRI definition of materiality and guidelines for non-financial material disclosure because it is more comprehensive and widely used by the companies all over the world (KPMG, 2015; Tiong and Anantharaman, 2011; Betianu, 2010; Borglund et al., 2010; Brown et al., 2009; KPMG Global Sustainability Services, 2008; Adams \& Frost, 2007; Frost et al., 2005). While, Ball et al., (2006, p.268) note that, "GRI claims to provide the basis of worldwide standardized, comparable, reporting on the sustainability of (particularly business) organizations." This statement is substantiated by Figure 1 , which shows the extent to which companies globally are reporting non-financial sustainability information using the GRI framework based on different geographical regions.

Figure 1 shows an increasing trend in global sustainability reporting. Between 1999 and 2016 there has been an increase from 12 to 4131 the number of organizations reporting sustainability information according to the GRI database. European and Asian organizations are in leading positions for sustainability reporting.

Figure 1: Region wise global sustainability reporting status from 1999 to 2016

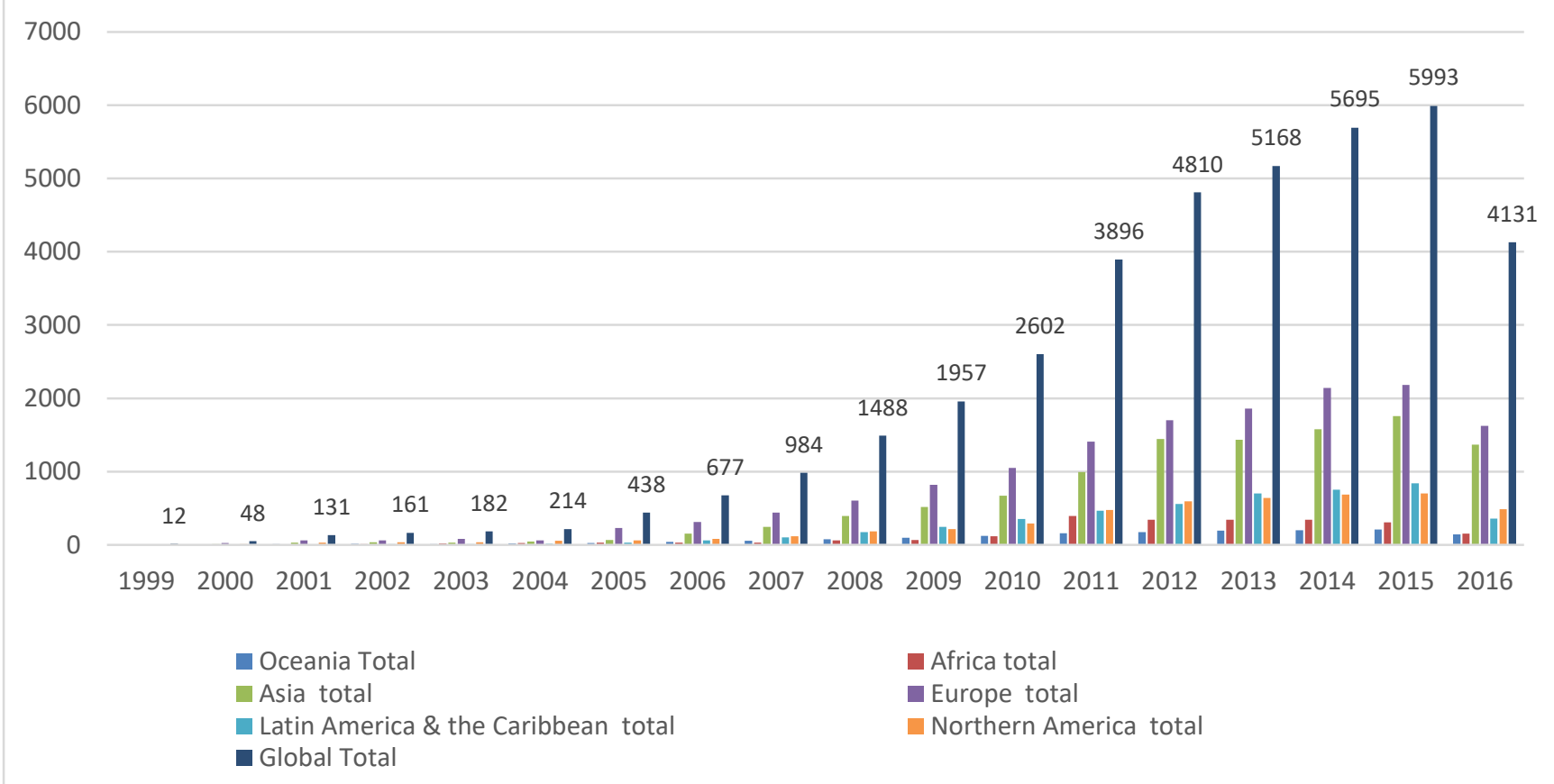

Source: Compiled from complete version of GRI Reports List (2017), Global Reporting Initiative https://www.globalreporting.org/services/Analysis/Reports_List/Pages/default.aspx

GRI introduced the first-generation sustainability reporting guidelines in 2000, the second generation (GRI G2) in 2002, the third generation (GRI G3) in 2006, the extended third generation (GRI G 3.1) in 2011 and fourth generation (GRI G4) in May 2013, (Global Reporting Initiative, n.d.). According to these guidelines, sustainability reporting "is a process that assists organizations in setting goals, measuring performance and managing change towards a sustainable global economy - one that combines long-term profitability with social responsibility and environmental care" (GRI, 2013a, p. 85). Table 2 presents the summary of GRI G4 sustainability reporting guidelines. 
Table 2: The GRI G4 guideline summary

\begin{tabular}{|l|l|}
\hline Disclosure Category & Items \\
\hline General disclosures & 1. Strategy and Analysis (G4-1 to G4-2) \\
& 2. Organizational Profile (G4-3 to G4-16) \\
& 3. Identified Material Aspects and Boundaries (G4-17 to G4 23) \\
& 4. Stakeholder Engagement (G4-24 to G4-27) \\
& 5. Report Profile (G4-28 to G4-33) \\
& 6. Governance (G4-34 to G4-55) \\
7. Ethics and Integrity (G4-56 to G4-58)
\end{tabular}

Source: Global Reporting Initiative. (2013b, pp.19-22).

The first section, general disclosure, covers a company's information on seven different issues mentioned in table 1 . The second section discloses specific standard disclosure on management approach in six different issues (economic; environmental; and social: labour practices and decent work, human rights, society, product responsibility) of sustainability. The final section of GRI G4 guideline consists specific standard disclosure and performance indicators related with economic, environmental; and social (labour practices and decent work, human rights, society, product responsibility) aspects of sustainability reporting. There are 91 specific standard disclosure and performance indicators in GRI G4 guidelines covering economic, environmental and social indicators.

In GRI guidelines, materiality determination in sustainability reporting considers economic, environmental, and social impacts. The GRI G4 guidelines underscore the meaning of materiality in sustainability reporting and it the core of these guidelines. These guidelines are not merely a data gathering exercise; rather these guidelines focus only on the most important aspects (material aspects) of sustainability reporting. In regard to the coverage of the report, GRI in their G4 implementation manual postulates, "The report should include coverage of material Aspects and their Boundaries, sufficient to reflect significant economic, environmental and social impacts, and to enable stakeholders to assess the organization's performance in the reporting period" (Global Reporting Initiative, 2013b, p. 12). GRI has articulated the materiality aspects and boundaries so report an organization's sustainability reporting issues on economic, environmental and social aspects. GRI considers its disclosures standards and guidelines on economic, environmental and social aspects as material (Global Reporting Initiative, 2013b).

To identify material aspects, GRI provides guidance on conducting a materiality assessment by following a four-step process, which includes: (1) identification of the aspects their boundaries, relevant for reporting; (2) prioritisation of the aspects from Step 1 to identify the materiality of those aspects; (3) validation of the identified aspects for finalising the report content; and (4) review of the published sustainability report (GRI 2013b, pp. 32-39). All these steps in the materiality process refer to the stakeholder inclusiveness principle, which is a central element in the G4 Guidelines and emphasize the importance of engaging with stakeholders in identifying the material aspects while defining the report content (GRI 2013a).

\section{IMPLICATIONS IN THE BUSINESS ENTERPRISES}

Non-financial disclosure of material information related to various aspects of sustainability by Bangladeshi business enterprises is likely to be important for their stakeholders. As part of the effort to conserve the environment, bio-diversity and related issues, a number of laws and regulations are in place in Bangladesh. However, there are no standard guidelines set by any authority in Bangladesh for non-financial disclosure of material sustainability information, except for the banks 
and non-bank financial institutions. Bangladesh Bank, the central bank of Bangladesh, has developed a number of policy guidelines for disclosing the sustainability information and enforce it through different circulars to make it mandatory for the banks and non-bank financial institutions in Bangladesh following internationally accepted disclosure format like GRI (Hossain, 2017). Therefore, the majority of the companies' disclosure requirement in this regard is not mandatory.

Few banks and non-bank financial institutions are following GRI guidelines in Bangladesh as it is evidenced in some studies (Banerjee et al., 2017; Mahmud et al., 2017; Hossain et al., 2016; Islam, 2016; Khan, 2015; Khan et al., 2011). However, in Bangladeshi companies, the use of GRI guidelines which focuses on the disclosure of material nonfinancial sustainability information is almost absent. Belal (2000) shows that Bangladeshi companies (based on 30 annual reports of the companies) disclosed very limited information on environmental issues. It is important to note that, this study only focuses on environmental disclosures and ignored economic, and social disclosures. Combining economic, environmental, and social disclosure of a company may give a holistic view about a company's disclosure of nonfinancial material sustainability information.

There are guidelines for the public limited companies on how to disclose their information in financial statements, but nothing is said there about the companies' nonfinancial disclosure of material sustainability information. Bangladesh adopted International Accounting Standards (IASs) as Bangladesh Accounting Standards (BASs, http://www.icab.org.bd/icabweb/webGeneralContent/ view /121092) on 1 January 2013, and for that Bangladeshi public limited companies must comply the International Accounting Standard (http: / / www.icab.org.bd/icabweb/webGeneralContent /view/391829) for the presentation of financial statement. Therefore, all the listed companies in the stock exchange must follow the guidelines mentioned in IAS 1. There is a provision of materiality regarding omissions and misstatements of financial information. Nonetheless, nothing is mentioned there regarding the non-financial disclosure of material sustainability information.

The position of Bangladesh is $4^{\text {th }}$ (10 organizations) among the eight-member South Asian Association for Regional Cooperation (SAARC) countries (Table 3) in reporting sustainability information. India remains highest (166 organizations), followed by Pakistan (21 organizations) and Sri Lanka (18 organizations). It is evident from table 3 that, the number of sustainability reporting in Bangladesh is very poor compared to India, Pakistan and Sri Lanka. There is ample scope for the Bangladeshi business enterprises to enhance their reporting on non-financial sustainability information.

Table 3: Sustainability reporting organizations in SAARC Countries (From 1999 to 2016)

\begin{tabular}{|c|c|c|}
\hline Country/Region & $\begin{array}{c}\text { No. of Reported } \\
\text { Organization }\end{array}$ & No. of Report \\
\hline Afghanistan & 0 & 0 \\
\hline Bangladesh & $\mathbf{1 0}$ & $\mathbf{2 5}$ \\
\hline Bhutan & 0 & 0 \\
\hline India & 166 & 525 \\
\hline Maldives & 0 & 0 \\
\hline Nepal & 0 & 0 \\
\hline Pakistan & 21 & 66 \\
\hline Sri Lanka & $\mathbf{1 8}$ & $\mathbf{7 4}$ \\
\hline SAARC & $\mathbf{2 1 5}$ & $\mathbf{6 9 0}$ \\
\hline World & $\mathbf{1 0 0 3 1}$ & $\mathbf{3 7 9 6 8}$ \\
\hline
\end{tabular}

Source: Compiled from

http:/ / database.globalreporting.org/search/

Although, the number of organizations reporting sustainability information is very low in Bangladesh, it is interesting that the companies who are reporting the sustainability issues, are following GRI guidelines while reporting their sustainability information, as evident in table 4 .

Table 4: Sustainability Reporting Organizations in Bangladesh based on GRI guidelines (from 1999 to 2016)

\begin{tabular}{|l|l|l|l|}
\hline Name & Size & Sector & Reports \\
\hline Bank Asia & MNE & Financial Services & $\begin{array}{l}2016 \text { - GRI G4, 2015 - GRI G4 , 2014 - GRI G3.1 , } \\
2013 \text { - GRI G3.1 }\end{array}$ \\
\hline $\begin{array}{l}\text { Bangladesh Electrical Industries } \\
\text { Limited (BEIL) }\end{array}$ & Large & Financial Services & 2013 - GRI G3.1, 2012 - GRI G3.1 \\
\hline British American Tobacco Bangladesh & Large & Tobacco & 2006 - GRI G2, 2003 - GRI G2 \\
\hline DBL Group & Large & Textiles and Apparel & 2015 - GRI G4, 2014 - GRI G4 \\
\hline $\begin{array}{l}\text { Industrial Development Leasing } \\
\text { Company (IDLC) }\end{array}$ & Large & Financial Services & $\begin{array}{l}2016 \text { - GRI G4, 2015 - GRI G4, 2014 - GRI G3.1, } \\
2013 \text { - GRI G3.1, 2012 - GRI G3.1 }\end{array}$ \\
\hline Mutual Trust Bank Ltd. & Large & Financial Services & 2016 - GRI Referenced, 2015 - GRI G4 \\
\hline Prime Bank Limited & Large & Financial Services & 2016 - GRI G4, 2015 - GRI G4, 2014 - GRI G3.1 \\
\hline Robi Axiata Limited & MNE & Telecommunications & 2015 - GRI G4 \\
\hline Square Fashions & Large & Textiles and Apparel & 2011 - GRI G3 \\
\hline VIYELLATEX Group & Large & Textiles and Apparel & 2013 - GRI G3.1, 2011 - GRI G3, 2010 - Non GRI \\
\hline
\end{tabular}

Source: Compiled from http:/ / database.globalreporting.org/search/ 
In Bangladesh, only ten companies are disclosing their sustainability information following GRI guidelines. Based on the sector, disclosure of non-financial sustainability is the highest in the financial services sector (5 companies), followed by textiles and apparel sector ( 3 companies), tobacco sector (1 company), and telecommunications sector (1 company). The number of business enterprises who are reporting non-financial sustainability information based on GRI guidelines is considerably low in Bangladesh. Five companies started to disclose non-financial sustainability information based on non-GRI/ citing-GRI reports in 2017 in Bangladesh, of them 4 (Brac Bank Limited, Eastern Bank Limited, Janata Bank Limited, Southeast Bank Limited) are from the banking sector and one (Olympic) from the manufacturing sector (Hossain, 2017). GRI guidelines are being used all over the world as a benchmark guideline for non-financial disclosure of sustainability information.

The Bangladeshi companies can enjoy many benefits by disclosing non-financial material sustainability information to their stakeholders, such as: an increase in investors' confidence, improved efficiency in investor communication, enhanced coordination inside and outside the organization, as well as strengthened market reputation and leadership (Ernst and Young, 2014). In addition, a winwin situation between the company and its stakeholders may prevail if a company discloses material sustainability information (Eccles and Krzus, 2014). Increased disclosure of sustainability information by the companies through non-financial reporting helps to renew the trust of their stakeholders (including investors/shareholders, regulators, and consumers) in them as well as allowing the stakeholders to take informed decisions (Lydenberg, 2012). If the number of non-financial material sustainability reporting organization in Bangladesh increases gradually, the companies may reap the mentioned benefits. By using the widely used GRI G4 guidelines as a benchmark, the Bangladeshi companies may enhance their acceptability among their stakeholders.

The recent global business environment is experiencing close examination and thoughtful pressure from different stakeholders on issues related to a company's sustainability performance (Rezaee, 2015). The economic implications of environmental and social issues are increasingly being recognized by global economic bodies (World Economic Forum (WEF) 2014; Organization for Economic Cooperation and Development (OECD) 2015)). At the 2017 World Economic Forum (held in Davos-Klosters, Switzerland from January 17-20, 2017), global business leaders argued for a socially focused business model which embraces the United Nation's sustainable development goals (SDGs). The Better Business, Better World report prepared for the World Economic Forum states, "We anticipate much greater pressure on business to prove itself a responsible social actor, creating good, properly paid jobs in its supply chains as well as in its factories and offices. Business will need to demonstrate that it pays taxes where revenue is earned; abides by environmental and labour standards; respects the national politics and customs where it operates; integrates social and environmental factors in its investment decisions; and, above all, engages as a partner with others to build an economy that is more just" (Business \& Sustainable Development Commission 2017, p. 7-8). This evidently suggests that global economic and business leaders are underscoring a business case for supporting the issue of sustainability. Hence, the non-financial disclosure of material sustainability information by the Bangladeshi companies may be a competitive factor in the upcoming years.

The conceptual discussion on disclosure of material nonfinancial sustainability information may provide insights for policymakers and corporate leaders in Bangladesh for decisions regarding expansion of reporting requirements. The companies may increase their nonfinancial material sustainability information by following a more holistic disclosure approach on economic, environmental and social sustainability information. Holistic disclosure of sustainability information is likely to be important for company stakeholders, which is congruent with the stakeholder theory and legitimacy theory.

Recently, in March 2018, the UN Committee for Development Policy (CPD) after completion of its review of the LDC category, announced that Bangladesh had met the graduation criteria for the first time. (For details, please visit https://www.un.org/development/desa/dpad/least-

developed-country-category-bangladesh.html). This begins the graduation process for Bangladesh from earlier LDC status to developing country status, which could receive official Developing Country status by 2024. As a developing country, Bangladesh may face a challenge to attract foreign investment, and without having any preparation, Bangladeshi companies may lag behind other countries if they do not follow the global standards and best practices. Therefore, the non-financial disclosure of material sustainability information by following GRI guidelines may increase Bangladeshi companies' acceptability among the global investors.

\section{Conclusion}

The conceptual discussion on the non-financial disclosure of material sustainability information based on GRI G4 guidelines underscores the relevance of sustainability information disclosure for company value and growth. Finally, the evidence from this paper is likely to provide valuable information for corporate leaders and other policymakers in Bangladesh to adopt a guideline which may provide input for decisions regarding persistent expansion of non-financial sustainability reporting requirements. The study may create the foundation for subsequent research that would expand the analysis to Bangladeshi business enterprises in different sectors and produce evidence that would be generalizable across sectors. 


\section{REFERENCES}

Abbott, W. F., and Monsen, R. J. (1979). On the measurement of corporate social responsibility: Self-reported disclosures as a method of measuring corporate social involvement. Academy of Management Journal, 22(3), 501-515.

Adams, C. \& Frost, G. (2007). Managing social and environmental performance: Do companies have adequate information? Australian Accounting Review, 17(43), 2-11.

Amel-Zadeh, A. (2016). The Materiality of Nonfinancial Information: A Review of Theory and Empirical Evidence on Sustainability Disclosures, Corporate Social Responsibility and Responsible Investing. Available at: https:/ / papers.ssrn.com/sol3/papers.cfm?abstract_id=26645 47

Ball, A., Broadbent, J., and Jarvis, T. (2006). Waste management, the challenges of the PFI and 'sustainability reporting'. Business Strategy and the Environment, 15(4), 258-274.

Banerjee, P.K., Mustafa, M.S., Hossain, M.M. and Ahmed, I. (2017). Sustainability Reporting Practices in Banks of Bangladesh, Research Monograph, No. 31, Bangladesh Institute of Bank Management, Dhaka, Bangladesh.

Belal, A. R. (2000), Environmental reporting in developing countries: empirical evidence from Bangladesh, EcoManagement and Auditing, Vol. 7, pp. 114-121.

Betianu, L. (2010). Indicators of the Global Reporting Initiative regarding sustainable development. Annales Universitatis Apulensis : Series Oeconomica, 12(1), 15-24.

Borglund, T., Frostenson, M., and Windell, K. (2010). Increasing responsibility through transparency? Ministry of Enterprise Energy and Communications, Stockholm.

Brown, H., de Jong, M., and Levy, D. (2009). Building institutions based on information disclosure: Lessons from GRI's sustainability reporting. Journal of Cleaner Production, 17(6), 571-580.

Buchholz, R. A., \& Rosenthal, S. B. (2005). Toward a contemporary conceptual framework for stakeholder theory. Journal of Business Ethics, 58(1), 137-148.

Business \& Sustainable Development Commission. (2017). Better Business Better World-The report of the Business \& Sustainable Development Commission. Available at: http:/ / report.businesscommission.org/report.

Campbell, D., Craven, B., \& Shrives, P. (2003). Voluntary social reporting in three FTSE sectors: a comment on perception and legitimacy. Accounting, Auditing $\mathcal{E}$ Accountability Journal, 16(4), 558-581.

Cho, C., Michelon, G., Patten, D. \& Roberts, R. (2015). CSR disclosure: The more things change. Accounting, Auditing $\mathcal{E}$ Accountability Journal, 28(1), 14-35.

Choi, H., and Moon, D. (2016). Perceptions of Corporate Social Responsibility in The Capital Market. Journal of Applied Business Research (JABR), 32(5), 1507-1518.

Christofi, A., Christofi, P., \& Sisaye, S. (2012). Corporate sustainability: historical development and reporting practices. Management Research Review, 35(2), 157-172.

Cochran, P. L., and Wood, R. A. (1984). Corporate social responsibility and financial performance. Academy of Management Journal, 27(1), 42-56.
Crawford, E. and Williams, C. (2010). Should corporate social reporting be voluntary or mandatory? Evidence from the banking sector in France and the United States. Corporate governance, 10(4), 512-526.

Deegan, C. (2002). Introduction - the legitimising effect of social and environmental disclosures-a theoretical foundation. Accounting, Auditing \& Accountability Journal, 15(3), 282-311.

Deegan, C. and Rankin, M. (1997). The materiality of environmental information to users of annual reports. Accounting, Auditing \& Accountability Journal, 10(4), 562-58.

Dhaliwal, D. S., Radhakrishnan, S., Tsang, A., and Yang, Y. G. (2012). Non-financial disclosure and analyst forecast accuracy: International evidence on corporate social responsibility disclosure. The Accounting Review, 87(3), 723-759.

Eccles, R. G., and Krzus, M. P. (2014). Chapter 6, The Sustainable Value Matrix. The integrated reporting movement: Meaning, momentum, motives, and materiality. John Wiley \& Sons.

Eccles, R. G., Krzus, M. P., Rogers, J., and Serafeim, G. (2012). The Need for Sector-Specific Materiality and Sustainability Reporting Standards. Journal of Applied Corporate Finance, 24(2), 65-71.

Edgley, C., Jones, M. J., and Atkins, J. (2015). The adoption of the materiality concept in social and environmental reporting assurance: A field study approach. The British Accounting Review, 47(1), 1-18.

Elkington, J. (1997). Cannibals with forks. The triple bottom line of 21st century Business. New Society: Stony Creek, CT.

Ernst and Young. (2014, p.2). Disclosure effectiveness - What companies can do now. Ernst and Young Global Limited. Available

http://www.ey.com/publication/vwluassets/eydisclosure-effectiveness-what-companies-can-donow/\$file/ey-disclosure-effectiveness-what-companiescan-do-now.pdf

Faisal, F., Tower, G., \& Rusmin, R. (2012). Legitimising corporate sustainability reporting throughout the world. Australasian Accounting Business \& Finance Journal, 6(2), 19.

Flammer, C. (2013). Corporate social responsibility and shareholder reaction: The environmental awareness of investors. Academy of Management Journal, 56(3), 758-781.

Font, X., Guix, M., and Bonilla-Priego, M. J. (2016). Corporate social responsibility in cruising: Using materiality analysis to create shared value. Tourism Management, 53, 175-186.

Frost, G., Jones, S., Loftus, J. and Laan, S. (2005). A survey of sustainability reporting practices of Australian reporting entities. Australian Accounting Review, 15(1), 89-96.

G4 Development Process. (n.d.). Retrieved from https:/ / www.globalreporting.org/standards/g4/g4developments/Pages/default.aspx

Global Reporting Initiative, (n.d.). GRI history. Available at, https:/ /www.globalreporting.org/information/aboutgri/gri-history/Pages/GRI's\%20history.aspx

Global Reporting Initiative. (2013a). GRI G4 reporting principles and standard disclosures. Available at: https:/ / www.globalreporting.org/resourcelibrary/GRIG4 -Part1-Reporting-Principles-and-Standard-Disclosures.pdf 
Global Reporting Initiative. (2013b). GRI G4 implementation manual. Available

at: https://www.globalreporting.org/resourcelibrary/GRIG4 -Part2-Implementation-Manual.pdf

Global Reporting Initiative. (2014). Materiality in the context of the GRI reporting framework. Available at: https://www.globalreporting.org/information/g4/G3and G3-1/guidelines-

online/TechnicalProtocol/Pages/MaterialityInTheContext OfTheGRIReportingFramework.aspx

Gray, R. H.; Adams, C. A. \& Owen, D. (2014) Accountability, Social Responsibility and Sustainability. Accounting for Society and the Environment. United Kingdom: Pearson Education Limited.

Gray, R., Kouhy, R., and Lavers, S. (1995). Corporate social and environmental reporting: A review of the literature and a longitudinal study of UK disclosure. Accounting, Auditing and Accountability Journal, 8(2), 47-77.

Griffin, J. J., and Mahon, J. F. (1997). The corporate social performance and corporate financial performance debate: Twenty-five years of incomparable research. Business $\mathcal{E}$ Society, 36(1), 5-31.

Guthrie, J., and Parker, L. D. (1989). Corporate social reporting: a rebuttal of legitimacy theory. Accounting and Business Research, 19(76), 343-352.

Herremans, I. M., Nazari, J. A., \& Mahmoudian, F. (2016). Stakeholder relationships, engagement, and sustainability reporting. Journal of Business Ethics, 138(3), 417-435.

Ho, J. and Taylor, M. (2007). An empirical analysis of triple bottom-Line reporting and its determinants: Evidence from the United States and Japan. Journal of International Financial Management \& Accounting, 18(2), 123-150.

Hossain, D. M., A.T. Bir., Ahmed, K.M. Tarique, A. Momen. (2016). Disclosure of Green Banking Issues in the Annual Reports : A Study on Bangladeshi Banks. Middle East Journal of Business, Vol 11 (1). 19-30.

Hossain, M.M. (2017). Sustainability Reports of Financial Services Industry in SAARC Countries: Special Reference to Bangladesh. Independent Business Review, Vol. 10 (1 \& 2).

International Integrated Reporting Council. (2013). The international $<I R>$ framework. Available at: http:/ /integratedreporting.org/wpcontent/uploads/2015/03/13-12-08-THEINTERNATIONAL-IR-FRAMEWORK-2-1.pdf

Islam, M.T. (2016). Green \& Sustainability Reporting and Legitimacy in the Banking Industry: Bangladesh Perspective, paper presented in Annual Banking Conference 2016, Bangladesh Institute of Bank Management, Dhaka, Bangladesh.

Jones, P., Comfort, D., \& Hillier, D. (2016). Materiality in corporate sustainability reporting within UK retailing. Journal of Public Affairs, 16(1), 81-90.

Kang, C., Germann, F., \& Grewal, R. (2016). Washing Away Your Sins? Corporate Social Responsibility, Corporate Social Irresponsibility, and Firm Performance. Journal of Marketing, 80(2), 59-79.

Khan, M. T. A. (2015). Sustainability Reporting under Global Reporting Initiative (GRI), The Cost And Management, Vol. 43 , No. 5, pp. 04-17.
Khan, M., Serafeim, G., and Yoon, A. (2016). Corporate sustainability: First evidence on materiality. The Accounting Review, 91(6), 1697-1724.

Khan, M.H.U.Z, Islam, M.A., Fatima, J.K. and Ahmed, K. (2011). Corporate Sustainability Reporting of Major Commercial Banks in Line with GRI: Bangladesh Evidence, Social Responsibility Journal, Vol. 7, No. 3, pp. 347 - 362.

KPMG Global Sustainability Services. (2008). International survey of corporate responsibility reporting 2008, Amstelveen.

KPMG International Cooperative. (2015). Currents of change: The KPMG survey of corporate responsibility reporting 2015.

Laplume, A. O., Sonpar, K., \& Litz, R. A. (2008). Stakeholder theory: Reviewing a theory that moves us. Journal of management, 34(6), 1152-1189.

Lin, C. H., Yang, H. L., and Liou, D. Y. (2009). The impact of corporate social responsibility on financial performance: Evidence from business in Taiwan. Technology in Society, 31(1), 56-63.

Lindblom, C. K. (1994). The implications of organizational legitimacy for corporate social performance and disclosure. In Critical Perspectives on Accounting Conference, New York (Vol. 120).

Lins, K. V., Servaes, H., and Tamayo, A. (2016). Social capital, trust, and firm performance: the value of corporate social responsibility during the financial crisis. The Journal of Finance.

Lu, W., \& Taylor, M. E. (2015). Which Factors Moderate the Relationship between Sustainability Performance and Financial Performance? A Meta-Analysis Study. Journal of International Accounting Research, 15(1), 1-15.

Lydenberg, S. (2012). On materiality and sustainability: The value of disclosure in the capital markets. Cambridge, $M A$ : Initiative for Responsible Investment. Available at: http://www.sasb.org/wp-content/uploads/2012/10/OnMateriality-and-Sustainability.pdf

Mahmud, M.S., Biswas, T. and Islam, M.N. (2017). Sustainability Reporting Practices and Implications of Banking Sector Bangladesh according to Global Reporting Initiative (GRI) Reporting Framework: An Empirical Evaluation, International Journal of Business and Management Invention, Vol. 6, No. 3, pp. 1-14.

McWilliam, A., and Siegel, D. (2001). Corporate social responsibility: A theory of the firm perspective. Academy of Management Review, 26(1), 117-127.

Milne, M. J., \& Gray, R. (2013). W(h)ither ecology? The triple bottom line, the global reporting initiative, and corporate sustainability reporting. Journal of business ethics, 118(1), 13-29.

Moskowitz, M. (1972). Choosing socially responsible stocks. Business and Society Review, 1(1), 71-75.

Neu, D., Warsame, H., \& Pedwell, K. (1998). Managing public impressions: environmental disclosures in annual reports. Accounting, Organizations and Society, 23(3), 265-282.

O'Donovan, G. (2002). Environmental disclosures in the annual report: Extending the appplicability and predictive power of legitimacy theory. Accounting, Auditing \& Accountability Journal, 15(3), 344-371. 
OECD. (2015). The Economic Consequences of Climate Change, OECD Publishing, Paris.

Ong, T., Trireksani, T., and Djajadikerta, H. G. (2016). Hard and soft sustainability disclosures: Australia's resources industry. Accounting Research Journal, 29(2), 198-217.

Parket, I. R., \& Eilbirt, H. (1975). The practice of business social responsibility: the underlying factors. Business Horizons, 18(4), 5-10.

Perez, F., and Sanchez, L. E. (2009). Assessing the evolution of sustainability reporting in the mining sector. Environmental Management, 43(6).

Reddy, K., \& Gordon, L. (2010). The effect of sustainability reporting on financial performance: An empirical study using listed companies. Journal of Asia Entrepreneurship and Sustainability, 6:2, 19-42.

Rezaee, Z. (2015). Business Sustainability: Performance, Compliance, Accountability and Integrated Reporting. Shefield, UK. Greenleaf Publishing Limited.

Rezaee, Z. (2016). Business sustainability research: A theoretical and integrated perspective. Journal of Accounting Literature, 36, 48-64.

Rezaee, Z. (2017). Corporate Sustainability: Theoretical and Integrated Strategic Imperative and Pragmatic Approach. Journal of Business Inquiry: Research, Education \& Application. Special Issue, Vol. 16 Issue 1, p 60-87

Russo, A., \& Perrini, F. (2010). Investigating stakeholder theory and social capital: CSR in large firms and SMEs. Journal of Business ethics, 91(2), 207-221.

Sturdivant, F. D., and Ginter, J. L. (1977). Corporate social responsiveness: Management attitudes and economic performance. California Management Review, 19(3), 30-39.

Sustainability Accounting Standards Board (SASB). (2016). Conceptual framework of the Sustainability Accounting Standards Board. Available at: Available at: http:/ /www.sasb.org/wpcontent/uploads/2016/04/SASB-Conceptual-Framework04.04.2016.pdf
Talcott, P. (1960). Structure and process in modern societies. United States, University of Michigan. New York, Free Press.

Tilling, M. V. (2004). Refinements in Legitimacy Theory in Social and Environmental Accounting. Commerce Research Paper Series No. 04-6. School of Commerce, Flinders University.

Tînjală, D. M. (2015). 2010-2014: A Comparative Evolution of Sustainability Reporting in Europe and the USA. Timisoara Journal of Economics and Business, 8(1s), 47-69.

Tiong, P. N., and Anantharaman, R. N. (2011). An examination of the sustainability disclosures of ANZ, NAB and Westpac. JASSA, (3), 12.

Tschopp, D., \& Huefner, R. J. (2015). Comparing the Evolution of CSR Reporting to that of Financial Reporting. Journal of Business Ethics, 127(3), 565-577.

Ullmann, A. A. (1985). Data in search of a theory: A critical examination of the relationships among social performance, social disclosure, and economic performance of US firms. Academy of Management Review, 10(3), 540-557.

Unerman, J., and Zappettini, F. (2014). Incorporating materiality considerations into analyses of absence from sustainability reporting. Social and Environmental Accountability Journal, 34(3), 172-186.

Van Dijken, F. (2007). Corporate social responsibility: market regulation and the evidence. Managerial Law, 49(4), 141-184.

Vance, S. C. (1975). Are Socially Responsible Corporations Good Investment Risks? Management Review, 64(8), 19-24.

Waddock, S. A., and Graves, S. B. (1997). The corporate social performance-financial performance link. Strategic Management Journal, 303-319.

World Commission on Environment and Development (WCED). (1987). The Brundtland Report: Our common future. Oxford: Oxford University Press.

World Economic Forum (WEF). (2014). Global Risks 2014. Available

at http://www3.weforum.org/docs/WEF_GlobalRisks_Rep ort_2014.pdf. 